\title{
Institutions and Cyclicality of the Fiscal and Monetary Policies in Brazil
}

\author{
Aline Gadelha ${ }^{1} \& J_{0}$ Á Angelo Divino ${ }^{1}$ \\ ${ }^{1}$ Graduate Program of Economics, Catholic University of Brasília, Brazil \\ Correspondence: José Angelo Divino, Graduate Program of Economics, Catholic University of Brasília, Brazil. \\ Campus I, QS 07 - Lote 01 - EPCT, Brasília/DF. Tel: 55-61-3448-7135. E-mail: jangelo@p.ucb.br
}

Received: January 19, 2021

Accepted: March 3, 2021

Online Published: March 10, 2021

doi:10.5539/ijef.v13n4p25

URL: https://doi.org/10.5539/ijef.v13n4p25

\begin{abstract}
This paper investigates the relationship between the quality of institutions and the cyclical properties of macroeconomic policies in the Brazilian economy in the recent period. We extend the monetary and fiscal policy rules proposed by Taylor (2000) to incorporate a proxy for institutional quality. In the empirical analysis, we estimate reaction functions for monetary and fiscal policies by the Markov-Switching method. This methodology allows us to analyze how changes in the quality of institutions might influence the guidance of the fiscal and monetary policies over the sample period. The major results maintain that both monetary and fiscal policies are significantly countercyclical in periods that exhibit higher levels of institutional quality and are pro-cyclical or acyclical in periods which exhibit lower levels of institutional quality. Thus, the quality of institutions plays a key role in the government's ability to implement countercyclical monetary and fiscal policies to stabilize the Brazilian economy over the business cycle.
\end{abstract}

Keywords: institutions, fiscal policy, monetary policy, business cycle, Markov-Switching

\section{Introduction}

The empirical literature that investigates the cyclical properties of macroeconomic policies argues that emerging countries, in general, tend to adopt pro-cyclical fiscal and monetary policies, while developed countries pursue countercyclical policies. Such behavior was observed in a distinct sample of countries and considered a stylized fact by many researchers, encouraging the emergence of a growing literature that seeks to explain the cyclicality of macroeconomic policies through theoretical and empirical models, e.g. Gavin and Perotti (1997), Melitz (2000), Braun (2001), Galí and Perotti (2003), Kaminsky, Reinhart, and Végh (2004), Talvi and Végh (2005), Alesina, Campante, and Tabellini (2008), Duncan (2014), Calderón, Duncan and Schmidt-Hebbel (2016), among others.

Considering the fiscal policy, emerging countries usually pursue pro-cyclical policies by increasing government spending or cutting taxes during economic booms and lowering spending or raising taxes in times of recession. This conduct of the fiscal policy strengthens the business cycle by accentuating booms and deepening recessions. Among the main reasons for this behavior are limited access to international credit markets and internal political distortions. Lack of access to credit markets in the downturn of the cycle leaves no alternative to governments other than cutting spending and raising taxes. Moreover, in times of booms it is difficult to resist political pressures for additional spending, especially when critical social areas heavily depend on government spending, as stressed by Vegh and Vuletin (2012).

Gavin and Perotti (1997) are among the first authors to claim that fiscal policy in Latin America is pro-cyclical. Later on, other researchers corroborated this idea, including Mailhos and Sosa (2000), Braun (2001), Sanchez de Cima (2003), Lane (2003), Kaminsky, Reinhart and Végh (2004), Talvi and Végh (2005), Manasse (2006), Sturzenegger and Wernek (2006), Ilzetzki (2007), and Strawczynski and Zeira (2007), Alesina, Campante and Tabellini (2008).

Talvi and Végh (2005) provided evidence that pro-cyclical fiscal policy appeared to be a general behavior among emerging countries and not just a particularity of Latin American countries. Alesina, Campante and Tabellini (2008) argued that internal political distortions might be used to explain this suboptimal fiscal outcome, highlighting the rules played by institutional fragility and widespread corruption as the main causes of this 
cyclical orientation.

In the monetary policy environment, the pro-cyclical behavior of emerging countries was documented mainly by Vegh and Vuletin (2012) through the so-called "fear of free fall". That is, in times of recession, characterized by large capital outflows, there is often strong exchange rate depreciation, forcing policymakers to raise interest rates. They argue that a fast depreciation of the national currency could further deepen the crisis in the economy by encouraging further capital outflows, which could lead to widespread bankruptcy of indebted foreign currency companies. Therefore, the need to raise interest rates to hold exchange rate depreciations prevent policy makers from adopting a countercyclical monetary policy.

Frankel, Vegh, and Vuletin (2011) break this pattern and provide evidence that in the last decade some emerging countries have shifted the direction of their fiscal and monetary policies from pro-cyclical to anticyclical. The main reason for this change in behavior was the improvement in the quality of institutions these countries have experienced, which translated into greater effectiveness of policy actions and adoption of rules and targets for both fiscal and monetary policies. Therefore, the quality of institutions seems to be a key determinant of a country's ability to adopt countercyclical policies.

Whereas many emerging markets undertook institutional reforms and pursued sounder macroeconomic management, Vegh and Vuletin (2012) believe that the "fear of free fall" has declined, or even disappeared, so that policymakers started using interest rate as an instrument of countercyclical monetary policy. Acemoglu et al. (2003) had already argued that institutional quality plays an important role in the performance of macroeconomic policies. They defended the idea that countries that adopt ineffective and distorted macroeconomic policies generally have weak economic and political institutions, which do not limit the power of politicians and the elite, ineffectively enforce property rights and are conniving with widespread corruption and political uncertainty. According to this view, the conduct of distorted macroeconomic policies is a symptom of underlying institutional problems.

Duncan (2014) formally addressed the role of institutions in the analysis of the business cycle. He developed a standard dynamic stochastic general equilibrium (DSGE) model to analyze the relationship between the quality of institutions and the cyclicality of the monetary policy. In this setup, a pro-cyclical policy, characterized by a negative correlation between the policy interest rate and the output gap, is expected in countries with weak institutions. This idea was corroborated by Calderón, Duncan and Schmidt-Hebbel (2016). They used a sample of 115 industrialized and emerging countries and found that countries with quality institutions are able to implement countercyclical monetary and fiscal policies, while pro-cyclical policies were observed in countries with weak institutions.

For the Brazilian case, however, the relationship between quality of institutions and cyclicality of macroeconomic policies has not been investigated in the literature yet. Brazil is an interesting case because it is an important emerging market economy that has faced profound institutional, political and economic transformations since the adoption of an inflation-targeting monetary policy regime in early 1999.

The objective of this paper is to investigate the relationship between the level of institutional quality and the cyclical properties of the macroeconomic policies in the Brazilian economy in the period from 1997 to 2017. More specifically, we examine how changes in the quality of the institutions that are responsible for implementing fiscal and monetary policies in the country influence the cyclical behavior of these policies over time. We extend the monetary and fiscal policy rules proposed by Taylor (2000) to incorporate a representative variable of institutional quality, given by the government stability indicator. Following Calderón et al. (2016), we add an interaction term between the output gap and the institutional quality indicator to the reaction functions of the fiscal and monetary policies. Thus, we insert a representative variable of institutional quality in the structural cyclically-oriented equations of macroeconomic policies in order to capture whether the level of institutional quality in a given period plays any role in the government's ability to adopt countercyclical or pro-cyclical macroeconomic policies.

Following North (1991) and Acemolglu et al (2005b), institutions correspond to the set of formal rules designed to conduct the macroeconomic policies, as well as the rules of political nature and political power distribution that influence such policies. In the empirical analysis, we admit the possibility of institutional change, reflecting on different levels of quality of institutions over time. In this framework, it is possible to identify how changes in the political and economic environments might have affected the management of the macroeconomic policies.

The quality of institutions is intrinsically related to the government's ability to effectively formulate and implement policies and regulations and to its commitment to meet pre-established targets. Regulatory quality, stability and integrity of the government, judicial effectiveness and protection of property rights are some 
measures that reflect the level of institutional quality. We use the Government Stability Index as a proxy for institutional quality. This index is a measure of the government's ability to execute its programs and to remain in power. It is one of the components of the political risk index of the International Country Risk Guide (ICRG), which considers institutional features related to government unity, legislative strength and popular support (Note 1). The values of the Government Stability Index range from 0 (lowest level of institutional quality) to 12 (highest level of institutional quality).

This variable is conceptually appropriate because it captures the perception of the government's ability to execute its policies effectively. In this sense, the lower the political stability, the greater the uncertainty regarding the proper and sustainable conduct of future economic policies. Ideally, a government should be able to execute sustainable policies through a strong and solid institutional framework.

In addition, the use of this index as a proxy for the level of institutional quality is based on the idea that countries with weak institutions are generally unable to properly cope with periods of economic uncertainty and financial volatility arising from internal crises, external distress and economic downturns. Consequently, higher institutional quality implies less instability and volatility of macroeconomic variables, as empirically evidenced by Gadelha and Divino (2019). Acemoglu, Johnson, and Robinson (2003) associate this relationship to the causal effect of institutions on economic volatility. Countries with weak institutions are more likely to experience higher economic volatility, which is intrinsically related to the degree of political and economic instability.

Given that Brazil has undergone wide institutional changes over the last 20 years directly related to the conduct of monetary and fiscal policies, we will consider the possibility of regime switching in our empirical analysis. These changes are related to the adoption of the inflation-targeting regime in 1999, the enactment of the Fiscal Responsibility Law in 2000, the Constitutional Amendment \#95 that established the public expenditure ceiling in 2016, among others. To account for these regime changes, we will apply the Markov-Switching method to estimate the fiscal and monetary policy reaction functions. This estimation method will allow us to identify how the level of institutional quality in a given period influences the cyclical orientation of the macroeconomic policies, portraying the dynamic relationship between these variables and accounting for changes in regime over time.

This paper contributes to the empirical literature by incorporating a time- varying role for the quality of institutions in the analysis of cyclical properties of macroeconomic policies through the estimation of the Markov-Switching models and application to the Brazilian case. The main findings suggest that both monetary and fiscal policies are significantly countercyclical in periods that exhibit higher levels of institutional quality and pro-cyclical or acyclical in periods that display lower levels of institutional quality. Thus, the level of institutional quality plays a key role in the government's ability to implement countercyclical monetary and fiscal policies to stabilize economic fluctuations over the business cycle.

The paper is organized as follows. The next section describes the econometric method used in the estimations. The third section presents and analyzes the results of the Markov-Switching estimates and the cyclicality of the macroeconomic policies. The fourth section is dedicated to concluding remarks.

\section{Method}

\subsection{Empirical Model}

Following Kaminsky, Reinhart, and Végh (2004), a countercyclical fiscal policy involves lower (higher) government spending and/or higher (lower) tax rates during boom (recession) periods. This policy is countercyclical because it seeks to stabilize the business cycle, being contractionary in periods of economic growth and expansionist in periods of recession. A pro-cyclical fiscal policy entails higher (lower) government spending and/or lower (higher) tax rates during boom (recession) periods. This policy is pro-cyclical because it strengthens the business cycle, being expansionary in periods of economic expansion and contractionary in periods of recession. Lastly, an acyclic fiscal policy is characterized by constant government spending and taxation throughout the business cycle, so that government spending and tax rates do not vary systematically across the economic fluctuations. This policy is acyclic because it does not strengthen or stabilize the business cycle.

The analysis of the cyclical properties of the monetary policy is more complex and demands the use of an implicit model. However, for countries that employ the base interest rate as a monetary policy instrument and follow a Taylor-type of interest rate rule, as is the case of Brazil, we might consider that countercyclical monetary policy occurs when the policy interest rate rises in economic booms and decreases in recessions, resulting in a positive correlation between the interest rate set by the monetary authority and the business cycle, 
measured by the output gap. A pro-cyclical monetary policy arises when the policy interest rate decreases in boom times and increases in periods of recession, resulting in a negative correlation between the base interest rate and the business cycle (output gap). Finally, an acyclic monetary policy takes place when the policy interest rate is not used as a policy instrument throughout the business cycle and is not correlated with the output gap.

In order to investigate the relationship between institutions and the cyclicality of the macroeconomic policies in Brazil, we extend the monetary and fiscal policy rules defined by Taylor (2000) to incorporate a proxy variable for institutional quality given by the indicator of government stability. Following Calderón et al. (2016), we add an interaction term between the output gap and the institutional quality indicator in both reaction functions, which might be written as:

$$
\begin{gathered}
\tilde{r}_{t}=\alpha_{0}+\alpha_{1} \tilde{r}_{t-1}+\alpha_{2} \tilde{\pi}_{t}+\alpha_{3} \tilde{e}_{t}+\alpha_{4} \tilde{y}_{t}+\alpha_{5} \tilde{y}_{t} I_{t}+\mathrm{u}_{\mathrm{t}} \\
\tilde{g}_{t}=\beta_{0}+\beta_{1} \tilde{g}_{t-1}+\beta_{2} \tilde{y}_{t}+\beta_{3} \tilde{y}_{t} I_{t}+v_{t}
\end{gathered}
$$

where are variables are expressed in deviations from a long run trend and are defined as:

$\tilde{r}_{t}=\left(r_{t}-\bar{r}\right)=$ policy interest rate;

$\tilde{\pi}_{t}=\left(\pi_{t}-\bar{\pi}\right)=$ inflation rate;

$\tilde{e}_{t}=\left(e_{t}-\bar{e}\right)=$ nominal exchange rate;

$\tilde{y}_{t}=\left(y_{t}-\bar{y}\right)=$ output gap;

$\tilde{g}_{t}=\left(g_{t}-\bar{g}\right)=$ government expenditure;

$I_{t}=$ indicator of institutional quality;

$u_{t}$ and $v_{t}=$ random error terms.

Equation (1) is a Taylor-type of interest rate rule. It is extended to include interest rate smoothing through the lagged dependent variable and deviations in the nominal exchange rate in addition to the traditional variables inflation and output gap. Equation (2) defines the fiscal policy rule as in Taylor (2000), where government spending depends on its lagged value and output gap. In both equations, we introduce an interaction term between the output gap and the institutional quality indicator, given by the government stability index for Brazil. This term intends to capture the relationship between the level of institutional quality and the cyclicality of the monetary and fiscal policies.

From equations (1) and (2), the coefficients of the lagged dependent variables $\alpha_{1}$ and $\beta_{1}$ are expected to be in the interval $(0,1)$ and the coefficients $\alpha_{2}$ and $\alpha_{3}$ of the monetary policy reaction function shall be positive. This would reflect the desire of the monetary authority to stabilize inflation and smooth out exchange rate fluctuations, respectively. Taylor (2000) defends the idea that the monetary authority might respond to exchange rate movements for different reasons, thus justifying the inclusion of this variable in the policy reaction function.

The coefficients $\alpha_{4}$ and $\alpha_{5}$ in equation (1) and $\beta_{2}$ and $\beta_{3}$ in equation (2) are used to determine the cyclical orientation of the monetary and fiscal policies, respectively, considering the indicator of institutional quality, whose proxy will be explained later. The coefficients $\alpha_{4}$ and $\alpha_{5}$ are expected to be negative and positive and statistically significant, reflecting the fact that for higher levels of institutional quality, monetary policy is expected to be countercyclical; while for lower levels of institutional quality, monetary policy should be pro-cyclical. If they are not statistically significant, the monetary policy is acyclic and insensitive to changes in the level of institutional quality.

The coefficients $\beta_{2}$ and $\beta_{3}$ of the fiscal policy rule should be positive and negative, respectively, indicating that for higher levels of institutional quality, the fiscal policy is expected to be countercyclical; while for lower levels of institutional quality, fiscal policy should be pro-cyclical. Likewise, if the coefficients $\beta_{2}$ e $\beta_{3}$ are not statistically significant, the fiscal policy is acyclic and insensitive to changes in institutional quality.

This framework permits the calculation of the country's institutional quality threshold, which is associated to an acyclical policy orientation, i.e., the inflection point of institutional quality at which policy is neither countercyclical nor pro-cyclical. This point is obtained from the partial derivative of the policy rule with respect to the output gap, given by the conditions that follow.

Monetary policy reaction function:

$$
\begin{gathered}
\frac{\partial \tilde{r}_{t}}{\partial \tilde{y}_{t}}=\alpha_{4}+\alpha_{5} I^{*}=0 \\
I^{*}=-\frac{\alpha_{4}}{\alpha_{5}}
\end{gathered}
$$


Fiscal policy reaction function:

$$
\begin{gathered}
\frac{\partial \tilde{g}_{t}}{\partial \tilde{y}_{t}}=\beta_{2}+\beta_{3} I^{*}=0 \\
I^{*}=-\frac{\beta_{2}}{\beta_{3}}
\end{gathered}
$$

From the estimated coefficients and the institutional quality threshold level for the inflection point, it is possible to infer the cyclical orientation of the macroeconomic policies within the analyzed period. Comparing the threshold of the institutional quality index with the average of the observed institutional quality indicator, it is possible to identify the cyclical behavior of each macroeconomic policy.

In the case of monetary policy, if the sample average of the observed institutional quality index is higher than the estimated inflection point $\left(I^{*}\right)$, then the partial derivative of the monetary policy rule with respect to the output gap is positive, indicating a positive correlation between the output gap and the policy interest rate. This result reflects a countercyclical monetary policy, where an increase in the output gap leads to a raise in the policy interest rate. Otherwise, if the average value of the institutional quality index is below $\left(\mathrm{I}^{*}\right)$, then the partial derivative is negative and the policy response to an increase in output gap is a decrease in the base interest rate, suggesting a pro-cyclical monetary policy.

$$
\begin{aligned}
& \text { if } I_{t}>I^{*}=-\frac{\alpha_{4}}{\alpha_{5}} \Rightarrow \frac{\partial \tilde{r}_{t}}{\partial \tilde{y}_{t}}>0 \Rightarrow \text { countercyclical monetary policy } \\
& \text { if } I_{t}<I^{*}=-\frac{\alpha_{4}}{\alpha_{5}} \Rightarrow \frac{\partial \tilde{r}_{t}}{\partial \tilde{y}_{t}}<0 \Rightarrow \text { pro-cyclical monetary policy } \\
& \text { if } I_{t}=I^{*}=-\frac{\alpha_{4}}{\alpha_{5}} \Rightarrow \frac{\partial \tilde{r}_{t}}{\partial \tilde{y}_{t}}=0 \Rightarrow \text { acyclical monetary policy }
\end{aligned}
$$

The first inequality indicates that the higher the level of institutional quality, the greater the likelihood of an anti-cyclical policy. The second inequality suggests that the lower the level of institutional quality, the greater the likelihood of a pro-cyclical policy.

In the case of the fiscal policy, if the sample average of the institutional quality index is higher than the estimated inflection point $\left(I^{*}\right)$, then the fiscal policy tends to follow a countercyclical orientation. Otherwise, if the sample average institutional quality index is below $\left(I^{*}\right)$, then there is evidence of a pro-cyclical fiscal policies, raising public spending in periods of booms and decreasing it in times of recessions.

$$
\begin{aligned}
& \text { if } I_{t}>I^{*}=-\frac{\beta_{2}}{\beta_{3}} \Rightarrow \frac{\partial \tilde{g}_{t}}{\partial \tilde{y}_{t}}<0 \Rightarrow \text { countercyclical fiscal policy } \\
& \text { if } I_{t}<I^{*}=-\frac{\beta_{2}}{\beta_{3}} \Rightarrow \frac{\partial \tilde{g}_{t}}{\partial \tilde{y}_{t}}>0 \Rightarrow \text { pro-cyclical fiscal policy } \\
& \text { if } I_{t}=I^{*}=-\frac{\beta_{2}}{\beta_{3}} \Rightarrow \frac{\partial \tilde{g}_{t}}{\partial \tilde{y}_{t}}=0 \Rightarrow \text { acyclical fiscal policy }
\end{aligned}
$$

Thus, the cyclical orientation of the fiscal and monetary policies might be determined from the estimated coefficients for the output gap and the interaction term between the output gap and the proxy variable for institutional quality.

\subsection{Markov-Switching Estimation}

We consider the possibility of institutional change resulting in different levels of institutional quality over time. By institutions, we mean formal rules that might be quickly and deliberately changed through a centralized political process. Thus, institutional change is treated as a political process by means of which the rules are explicitly established and altered by a collective political entity, namely, the government.

Brazil has undergone significant institutional changes over the past 20 years, directly related to the conduct of monetary and fiscal policies. They resulted from the adoption of the inflation-targeting regime in mid-1999, the enactment of the Fiscal Responsibility Law in 2000, and Constitutional Amendment \#95 for the public expenditure ceiling in 2016, among others. To capture these institutional changes in both the monetary and fiscal instances, we will consider in our empirical analysis the possibility of regime switching during the sample period. 
Thus, we estimate the reaction functions of fiscal and monetary policies, given by equations (1) and (2), by the Markov-Switching procedure. The linearity hypothesis of the model is relaxed and we formally allow for the possibility of regimes switching during the analyzed period. The Markov-Switching model considers the possibility that at any moment in time a finite number of "regimes" or "states" might occur without anyone knowing exactly which one is being observed. Changes in states or regimes are not deterministic, assuming that there are probabilities of transition from one regime to another, which are endogenously estimated within the model (Note 2). By using the Markov-Switching method, the functional forms of the estimated reaction functions of monetary and fiscal policies assume the following specifications:

$$
\begin{gathered}
\tilde{r}_{t}=\alpha_{0}+\alpha_{1} \tilde{r}_{t-1}+\alpha_{2}\left(s_{t}\right) \tilde{\pi}_{t}+\alpha_{3}\left(s_{t}\right) \tilde{e}_{t}+\alpha_{4}\left(s_{t}\right) \tilde{y}_{t}+\alpha_{5}\left(s_{t}\right) \tilde{y}_{t} I_{t}+\sigma\left(s_{t}\right) u_{t} \\
\tilde{g}_{t}=\beta_{0}+\beta_{1} \tilde{g}_{t-1}+\beta_{2}\left(s_{t}\right) \tilde{y}_{t}+\beta_{3}\left(s_{t}\right) \tilde{y}_{t} I_{t}+\sigma\left(S_{t}\right) v_{t}
\end{gathered}
$$

where $u_{t} \sim N\left(0, \sigma^{2}\left(S_{t}\right)\right)$ and $v_{t} \sim N\left(0, \sigma^{2}\left(S_{t}\right)\right)$. $S_{t}$ is a non-observable stochastic variable that determines state $\mathrm{k}$ that the model assumes at each period $\mathrm{t}$.

By assumption, $S_{t}$ is a latent variable, governed by a stochastic process known as the ergodic Markov chain, defined by a transition probability matrix. The probability of transition from regime $i$ to regime $j$ at $t+1$ is represented by $p_{i j}$. The process might alternate between regimes or states repeatedly over the sample period. The probability matrix reflects the idea that the likelihood of occurrence of a regime $S_{t}$ at present depends only on the regime that occurred in the previous period $S_{t-1}$ :

$$
\mathrm{P}\left(S_{t}=j \mid S_{t-1}=i, S_{t-2}=k, S_{t-3}=w \ldots\right)=\mathrm{P}\left(S_{t}=j \mid S_{t-1}=i\right)=p_{i j}
$$

Considering the various specifications of the Markov-Switching model, the three-regime model best fit the data for estimating the monetary policy rule according to the information criteria of Akaike, Hannan-Quinn and Schwarz. For the fiscal policy, the two-regime model best fit the data according to these same information criteria. These regimes are classified according to the cyclical orientation of the macroeconomic policy within the period as countercyclical, pro-cyclical and acyclical.

Initially, the estimation by Markov-Switching procedure allows for the estimated coefficients to change according to alternative policy regimes. This makes it possible to calculate the level of institutional quality that corresponds to the inflection point for each regime, where the policy is neither countercyclical nor pro-cyclical. As discussed in the previous section, this point is calculated from the partial derivative of the policy rule function with respect to the output gap.

Subsequently, we compare this threshold of the institutional quality index $\left(I^{*}\right)$ with the sample average of the institutional quality indicator for the period within each regime. From this comparison, we infer on the cyclical behavior of the monetary and fiscal policy that predominates within each regime.

\section{Results}

\subsection{Data}

The data set is monthly and comprises the period from 1997 to 2017. The variables are expressed in deviations of the observed values from a long run trend estimated by the HP filter, as proposed by Hodrick and Prescott (1997). Thus, the deviations correspond to the cyclical component of each time series, estimated by the HP filter. In addition of being a method of simple implementation, the HP filter is widely used in the economic literature and has the advantage of rendering stationarity to the filtered series, as shown by King and Rebelo (1993). Despite of some criticisms, the HP filter has been widely used by the empirical literature in Brazil, especially to estimate the output gap, where it performs better than other methods by considering distinct criteria of comparison (Note 3). The time series along with their sources are described in sequence.

The policy interest rate $\left(\tilde{r_{t}}\right)$ is represented by the cyclical component of the Selic Overnight rate in annualized percentage points. This rate is the monetary policy instrument in the inflation targeting regime. The source was the Central Bank of Brazil.

The output gap $\left(\tilde{y_{t}}\right)$ corresponds to the cyclical component of the observed real gross domestic product (GDP), in percentage points. The monthly nominal GDP was obtained from the Central Bank of Brazil. It was deflated by the wide consumer price index (IPCA) and seasonally adjusted by the Census X-12-ARIMA.

The inflation rate $\left(\tilde{\pi_{\mathrm{t}}}\right)$ is the cyclical component of the monthly change in the wide consumer price index (IPCA), which is the price-variation reference in the inflation targeting regime. The source was the Brazilian Institute of Geography and Statistics (IBGE).

The government expenditure $\left(\tilde{g_{t}}\right)$ is given by the cyclical component of the logarithm of the primary public 
expenditure (Note 4). The nominal series was deflated by the wide consumer price index (IPCA) and seasonally adjusted by the Census X-12-ARIMA. The source was the National Treasury Secretariat.

The exchange rate $\left(\tilde{\mathrm{e}_{t}}\right)$ is represented by the cyclical component of the nominal exchange rate between the BRL and USD in logs. The source was the Central Bank of Brazil.

The proxy for the institutional quality index (I) is given by the Government Stability Index, which measures the government's ability to execute its programs and remain in power. It is a component of the political risk index of the International Country Risk Guide (ICRG). The Government Stability Index series ranges from 0 (lowest level of institutional quality) to 12 (highest level of institutional quality).

Figure 1 illustrates the trajectory of the Government Stability Index during the period from 1997 to 2017. The dynamics of the index indicates that the highest level of institutional quality was observed in the first months of 2000. This period followed the adoption of the inflation-targeting regime by the monetary policy and the primary surplus rule by the fiscal policy. In addition, the exchange rate policy shifted to a floating regime and the Fiscal Responsibility Law was promulgated in this period. Thus, the highest level of the institutional quality index reflects these important changes in the guidance of Brazilian macroeconomic policies.

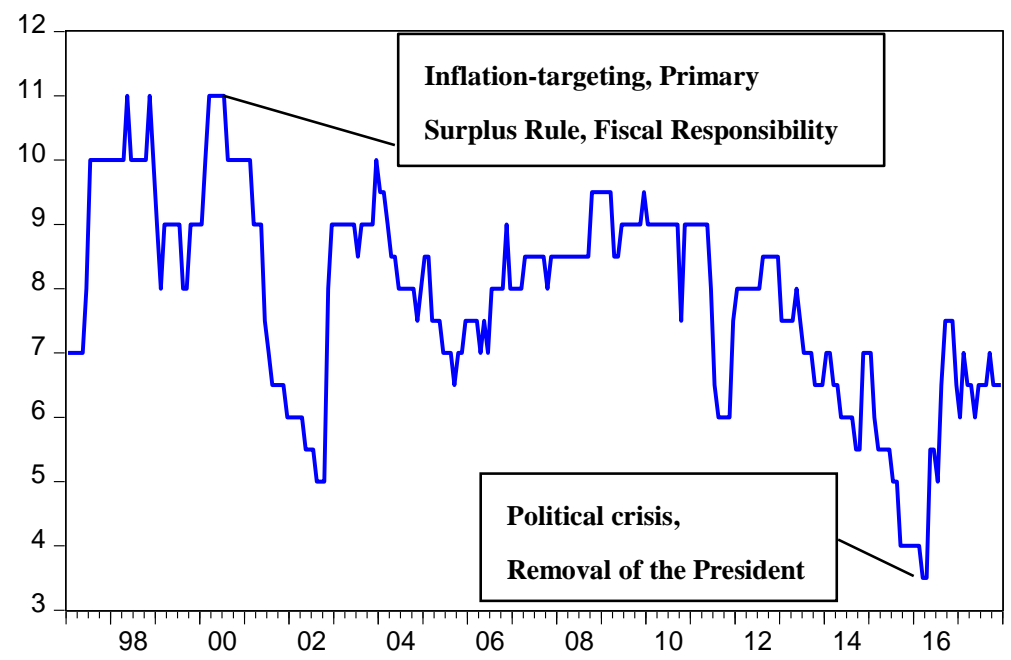

Figure 1. Government stability index (1997-2017)

Source: International Country Risk Guide (ICRG).

On the other hand, the lowest level of the index (3.5 points) was registered in March and April of 2016. These months characterize a moment of great economic instability and political crisis in the country, which culminated with the removal of President Dilma Rousseff from office in May 2016, following the decision of the Brazilian National Congress to initiate an impeachment process against the President. It is worth mentioning that the main accusations to support the President's removal request were the so-called "fiscal pedaling" (fiscal irregularities) and signature of budget supplementary decrees without congressional authorization, thus reflecting weakness of the fiscal institutions in the country. Moreover, this weakness was also evidenced during the same period when the congress eased the fiscal target and authorized the federal government to end the fiscal year with a negative primary result.

The descriptive statistics of the time series in levels are summarized in Table 1 (Note 5). The stationarity of the time series was verified by performing several unit root tests. Initially, we applied the modified versions of the Dickey-Fuller (MADFGLS) and Phillips-Perron (MPPGLS) tests, as proposed by Elliot, Rottemberg and Stock (1996) and Ng and Perron (2001), respectively (Note 6). For some of the macroeconomic variables, the null hypothesis of unit root was not rejected. This finding, however, might be biased due to presence of structural break in these series, a common feature of the Brazilian time series in the sample period. To avoid this bias, we applied the unit root test proposed by Perron (1997), which allows for different types of structural breaks with endogenous selection of the breaking time. The results indicated that the macroeconomic series are all stationary once we allow for the presence of structural breaks. The results are reported in Table A1 of the Apendix. 
Table 1. Descriptive statistics

\begin{tabular}{lccccc}
\hline \multicolumn{1}{c}{ Variable } & $\mathrm{N}$ & Average & Stand. dev. & Min. & Max. \\
\hline Nominal interest rate (\%, annualized) & 252 & 15.63389 & 6.820772 & 6,08 & 48.23 \\
Monthly GDP (R \$ mi, constant) & 252 & 267726.8 & 158089.7 & 70461.6 & 588470.8 \\
Monthly Inflation rate (\%) & 252 & 0.5110 & 0.3889 & -0.51 & 3.02 \\
Primary gov. expend. (R \$ mi, constant) & 252 & 74787.09 & 29144.24 & 32810.55 & 191558 \\
Exchange rate (R /US\$) & 252 & 2.2595 & 0.6946 & 1.0421 & 4.0517 \\
Government Stability Index (0 to 12) & 252 & 7.89 & 1.59 & 3.5 & 11 \\
\hline
\end{tabular}

Note. The wide consumer price index (IPCA, with June/2018=100) was used as deflator for the GDP and primary government expenditure.

\subsection{Institutional Quality and Cyclicality of the Monetary Policy}

The results for the estimated Markov-switching model of the monetary policy are reported in Table 2. Considering various alternative specifications, the three-regime model produced the best fit to the data according to the Akaike, Hannan-Quinn and Schwarz information criteria. The three-regime model presented strong convergence and rejected the null hypothesis of linearity according to the likelihood ratio (LR) test.

In the first regime, the estimated monetary authority's reaction function is characterized by positive and statistically significant responses to inflation and the exchange rate. In the long-run equilibrium, the implied response to inflation variation is greater than one, as preconized by the Taylor principle (Note 7). The response to the output gap, however, was not statistically significant, suggesting that the monetary policy did not react to output gap variations under the first policy regime.

This finding also implies that the monetary policy was acyclical during the short period of regime 1, from 1997 to 1999 according to Figure 2. This classification combines the definition by Kaminsky, Reinhart and Végh. (2004) on the cyclical orientation of monetary policy and the interpretation proposed by Calderón et al. (2016), as previously explained in section 2 . This acyclic behavior might be related to asymmetries in the monetary policy in response to economic fluctuations, so that the interest rate does not vary systematically across the business cycle. In this case, the monetary authority might adopt either expansionist or contractionist policies in either phase of the business cycle without affecting the economic activity.

It is important to notice that regime 1 corresponds to the sample period preceding the institutional change implied by the adoption of the inflation-targeting regime in Brazil. This period was characterized by a quasi-fixed exchange rate regime, in which the policy interest rate was used to keep the exchange rate within predefined intervals of fluctuations. The currency anchor was an effective policy to control inflation during this period.

In a scenario of speculative attacks against the domestic currency, in March of 1999 the Central Bank of Brazil decided to abandon the currency anchor regime and formally announced its intention to adopt inflation targeting coupled with floating exchange rate. In June of 1999, the country formally announced the inflation-targeting regime as a guideline for the monetary policy through the $9^{\text {th }}$ edition of Decree No. 3,088 and Resolution No. 2,615 of the National Monetary Council (CMN).

In regime 2, the monetary authority responds to variations in the inflation rate and the output gap, whose coefficients have signs as expected and described in the previous section. In other words, the coefficient for inflation is positive, the coefficient for the output gap is negative, while the coefficient for the interaction term is positive, as reported in Table 2. Both the coefficients for the output gap and the interaction term are statistically significant. These coefficients are used to calculate the inflection point of the institutional quality index. At this point, there might be a change in the cyclical orientation of the monetary policy. As explained earlier, this point is given by the partial derivative of the policy rule's function with respect to the output gap. 
Table 2. Markov-Switching model for the monetary policy rule

\begin{tabular}{lccc}
\hline Variables & Regime 1 & Regime 2 & Regime 3 \\
\hline Constant & $-0.000060^{*}$ & $-0.000060^{*}$ & $-0.000060^{*}$ \\
& $(0.0516)$ & $(0.0516)$ & $(0.0516)$ \\
Lagged policy interest rate & $0.605395^{* * *}$ & $0.605395^{* * *}$ & $0.605395^{* * *}$ \\
& $(0.0000)$ & $(0.0000)$ & $(0.0000)$ \\
Inflation & $0.545313^{* * *}$ & $0.021137 * * *$ & 0.028215 \\
& $(0,0000)$ & $(0.0051)$ & $(0.0000)$ \\
Exchange rate & $0.022364^{* * *}$ & 0.002497 & -0.000438 \\
& $(0.0009)$ & $(0.1476)$ & $(0.5424)$ \\
Output gap & 0.048277 & $-0.016728^{* * *}$ & $-0.009779^{* * *}$ \\
& $(0.9966)$ & $(0.0001)$ & $(0.0000)$ \\
Output gap X Institutional Quality Index & $0.018915^{* * *}$ & $0.001669^{* * *}$ & $0.002072^{* * * *}$ \\
& $(0.0000)$ & $(0.0013)$ & $(0.0000)$ \\
Log(sigma) & $-6.194367 * * *$ & $-6.590879^{* * *}$ & $-7.392559^{* * * *}$ \\
& $(0.0000)$ & $(0.0000)$ & $(0.0000)$ \\
Observations & 252 & 252 & 252 \\
Average duration & 3.16 & 201.70 & 33.29 \\
Log likelihood & 1379.815 & & \\
LR-Test $\chi^{2}$ & $97.71314^{* * *}$ & & \\
Akaike & -10.85452 & & \\
Hannan-Quinn & -10.72413 & & \\
Schwarz & -10.53055 & & \\
\hline
\end{tabular}

Note. All variables are in deviations from a trend, as given by the cyclical component of the HP filter. ***, ** and * denote statistical significance at the $1 \%, 5 \%$ and $10 \%$, significance levels, respectively. P-values are in parenthesis. - Common to all regimes.

From Table 3, the inflection point of the institutional quality indicator for regime 2 is 10.02 . This value is higher than the average of the institutional quality index for the period in which regime 2 predominated (7.45). Thus, the index average value is below the estimated inflection point, meaning that monetary policy followed a pro-cyclical orientation. This period, according to Figure 2, began in mid-2006 and persisted until the end of the sample in 2017 , covering about $55 \%$ of the whole sample. This regime is characterized by the longer average duration and high persistence, with a $97 \%$ probability of remaining in the same regime, as documented in Table 4.

Historically, at the beginning of regime 2, there was a consistent loosening of the monetary policy, characterized by the expansion of liquidity in the domestic market due to the credit expansion sponsored mainly by the public banks. The increase in lending was mostly used to finance consumption. The domestic scenario was marked by relative economic stability coupled with an international environment of economic growth and liquidity expansion.

The results for regime 3 indicate that the monetary authority reacts to the inflation deviation from the target, but is insensitive to the exchange rate deviation, since its coefficient is not statistically significant within this regime. Regime 3 comprises the period immediately after the adoption of the inflation-targeting regime in Brazil, in 1999, and extending until middle 2006 as illustrated in Figure 2.

Table 3. Institutional quality and cyclicality of the monetary policy

\begin{tabular}{lccc}
\hline & Regime 1 & Regime 2 & Regime 3 \\
\hline Output gap $\left(\alpha_{4}\right)$ & 0.0483 & -0.0167 & -0.0098 \\
Interaction term $\left(\alpha_{5}\right)$ & 0.0189 & 0.0017 & 0.0021 \\
Inflection point of institutional quality & Not significant & 10.0228 & 4.7196 \\
Sample average of the institutional quality indicator & & 7.4528 & 8.3413 \\
Monetary policy orientation & Acyclical & Pro-cyclical & Counter-cyclical \\
& & $7.4529<10.0228$ & $8.3413>4.7196$ \\
\hline
\end{tabular}

Table 4. Transition matrix for the monetary policy rule

\begin{tabular}{cccc}
\hline & Regime 1, $\mathrm{t}$ & Regime 2, $\mathrm{t}$ & Regime 3, $\mathrm{t}$ \\
\hline Regime 1, $\mathrm{t}+1$ & 0.6841 & 0.3159 & 0.0000 \\
Regime 2, $\mathrm{t}+1$ & 0.0242 & 0.9700 & 0.0058 \\
Regime 3, $\mathrm{t}+1$ & $4.88 \mathrm{E}-09$ & 0.0050 & 0.9950 \\
\hline
\end{tabular}


The estimated coefficients of output gap and institutions-output gap in regime 3 are statistically significant and the inflection point for institutional quality is 4.72 , as reported in Table 3. Comparing this estimated value with the average of the institutional quality indicator for the period in which regime 3 predominated (8.34), we can infer that the monetary policy exhibited a countercyclical behavior during this period. There is a robust and significant relationship between the cyclical guidance of the monetary policy in response to changes in the output gap and the level of institutional quality. The monetary policy is strongly anticyclical in periods with higher levels of institutional quality, as is the case of regime 3.

On the other hand, the monetary policy was significantly pro-cyclical in periods that exhibited lower levels of institutional quality, as in regime 1 , where the average of the institutional quality indicator was 7.45 . The quality level of the institutions are intrinsically related to the government's ability to effectively formulate and implement economic policies and to guarantee individual rights. Improvements in the institutional framework over the sample period can be explained by the implementation and proper conduct of new monetary policy rules. This shaped the policy to a greater commitment and compliance with the policy rules, thereby increasing its credibility, reducing uncertainties and mitigating distortions. Thus, the quality level of institutions plays an important role in the government's ability to guide a countercyclical monetary policy.
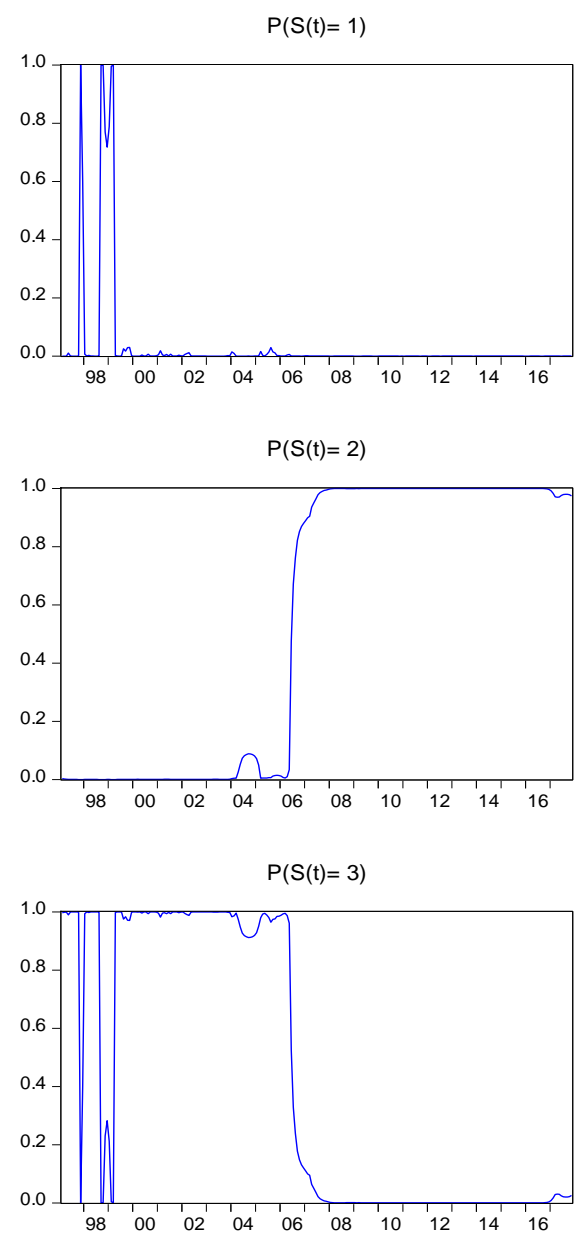

Figure 2. Monetary policy regimes: Markov-Switching smoothed probabilities

\subsection{Institutional Quality and Cyclicality of the Fiscal Policy}

The estimation results for the switching regime model of the fiscal policy reaction function are reported in Table 5. The two-regime model presented the best fit to the data according to the information criteria of Akaike, Hannan-Quinn and Schwarz. In addition, it showed strong convergence in the estimation. The likelihood ratio (LR) test rejected the null hypothesis of linearity within the model.

According to Table 5, in regime 1, both the output gap and the interaction term between institutions and output gap are statistically significant and have signs as expected within the policy regimes. The output gap estimated 
coefficients are positive, while the coefficients of interaction term are negative. As before, these coefficients are used to calculate the inflection point of the institutional quality index at which fiscal policy switches cyclical guidance. It is given by the partial derivative of the fiscal policy rule with respect to the output gap.

Table 5. Markov-Switching model for the fiscal policy rule

\begin{tabular}{|c|c|c|}
\hline Variables & Regime 1 & Regime 2 \\
\hline \multirow{2}{*}{ Constant $^{1}$} & -0.001443 & -0.001443 \\
\hline & $(0.0000)$ & $(0.0000)$ \\
\hline \multirow[t]{2}{*}{ Lagged dependent variable $^{1}$} & $0.993295^{* * *}$ & $0.993295 * * *$ \\
\hline & $(0.0000)$ & $(0.0000)$ \\
\hline \multirow[t]{2}{*}{ Output gap } & $0.005735^{* * *}$ & $0.021771 * * *$ \\
\hline & $(0.0016)$ & $(0.0000)$ \\
\hline \multirow[t]{2}{*}{ Output gap $x$ Institutional Quality Index } & -0.000586 & $-0.002944 * * *$ \\
\hline & $(0.0064)$ & $(0.0000)$ \\
\hline \multirow[t]{2}{*}{$\log ($ sigma $)$} & $-7.092114 * * *$ & $-7.092114 * * *$ \\
\hline & $(0.0000)$ & $(0.0000)$ \\
\hline Observations & 252 & 252 \\
\hline Average duration & 20.87644 & 7.035412 \\
\hline Sample average of the Institutional Quality Index & 7.8248 & 8.2075 \\
\hline Log likelihood & 1393.045 & \\
\hline LR-Test $\chi^{2}$ & $9.936963 * * *$ & \\
\hline Akaike & -11.06436 & \\
\hline Hannan-Quinn & -11.00767 & \\
\hline Schwarz & -10.92350 & \\
\hline
\end{tabular}

Note. All variables are in deviations from a trend, as given by the cyclical component of the HP filter. ***, ** and * denote statistical significance at the $1 \%, 5 \%$ and $10 \%$, significance levels, respectively. P-values are in parenthesis. 1- Common variables to all regimes.

From Table 6, the limit value of the institutional quality indicator (inflection point) for regime 1 is 9.79 . This value is higher than the sample average of 7.82 of the institutional quality indicator for the period in which regime 1 predominated. Thus, fiscal policy exhibited a pro-cyclical guidance during this period.

Regime 1 accounted for over $78 \%$ of the sample period, according to Figure 3, being less frequent only in the years of 2003, 2011 and 2017. This finding illustrates a strong tendency to pro-cyclicality in the conduction of Brazilian fiscal policy recently. In periods under which the Brazilian economy showed significant growth rates, with consequent increasing in tax revenues, primary government expenditure also expanded without prejudice of primary surplus generation. However, in periods of recession or low economic growth, the fiscal instance contributed to the downturn by incurring in significant deterioration of the fiscal result.

In regime 2, the fiscal policy reactions to the output gap and the institutions-output gap interaction term are also statistically significant. The estimated coefficients imply in inflection point of 7.39 for the change in fiscal policy guidance. Comparing this value with the sample average of 8.20 of the institutional quality indicator, we argue that the fiscal policy has exhibited countercyclical behavior within this regime.

Table 6. Institutional quality and cyclicality of the fiscal policy

\begin{tabular}{lcc}
\hline & Regime 1 & Regime 2 \\
\hline Output gap $\left(\beta_{2}\right)$ & 0.0057 & 0.0218 \\
Interaction tem $\left(\beta_{3}\right)$ & -0.0013 & -0.0029 \\
Inflection point of the institutional quality & 9.7867 & 7.3950 \\
Sample average of the institutional quality indicator $\left(I_{t}\right)$ & 7.8249 & 8.2075 \\
Fiscal policy orientation & Pro-cyclical & Counter-cyclical \\
\hline
\end{tabular}

Regime 2 is characterized by anticyclical behavior and exhibits very low frequency (22\%) when compared to regime $1(78 \%)$. Regime 2 is mostly prevalent in the years following the outbreak of the international financial 
crisis in 2008, persisting until 2011. After that, the fiscal policy returned to its typical pro-cyclical behavior, as illustrated in Figure 3.

Regimens 1 and 2 have an average duration of 20 and 7 months, respectively, and are considered highly persistent, with a $95 \%$ probability of remaining in regime 1 and $86 \%$ probability of staying in regime 2 , as reported in Table 7 . These results highlight that a highly persistent pro-cyclical guidance has predominated in the conduction of the Brazilian fiscal policy in the last 20 years. Moreover, the policy is significantly pro-cyclical in periods that exhibit lower levels of institutional quality.

A possible explanation for this finding is the existence of weaker institutions in the fiscal instance, which is more subject to political influence and private interests than the monetary policy. Over the last years, politicians have imposed limitations to the well-functioning of the two major fiscal institutions in force, the primary surplus targeting regime and the Law of Fiscal Responsibility. This has prevented them to achieve their primary objectives of balancing public finances and stabilizing the business cycle. Thus, the pro-cyclical guidance is directly associated with institutional weakness in the fiscal instance.

$P(S(t)=1)$

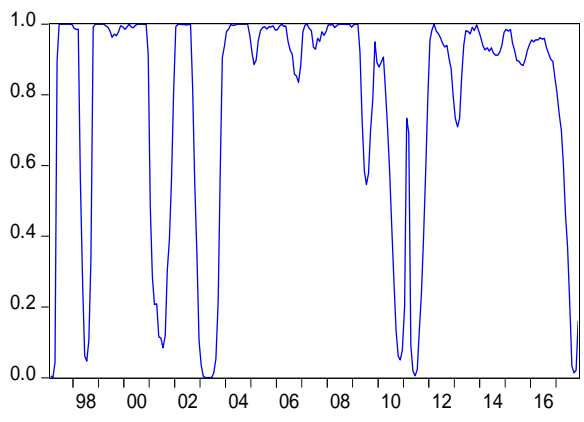

$P(S(t)=2)$

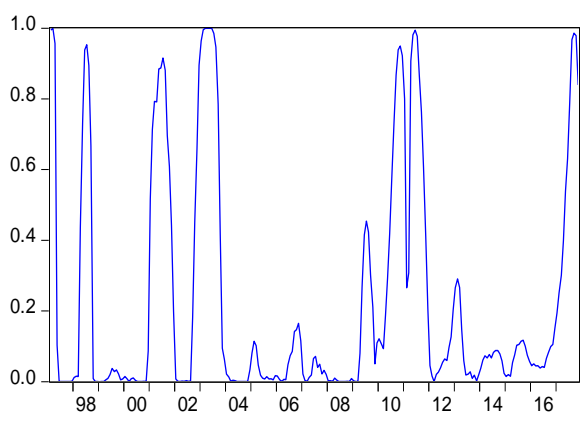

Figure 3. Fiscal Policy Regimes: Markov-Switching smoothed probabilities

Table 7. Transition matrix for the fiscal policy rule

\begin{tabular}{ccc}
\hline & Regime 1, & Regime 2, $\mathrm{t}$ \\
\hline Regime 1, $\mathrm{t}+1$ & 0.9521 & 0.0479 \\
Regime 2, $\mathrm{t}+1$ & 0.1421 & 0.8579 \\
\hline
\end{tabular}

In the fiscal environment, the primary surplus targeting regime and Law of Fiscal Responsibility represents a significant progress towards institutionalization of a responsible management of the fiscal policy. They played the important role of imposing primary surpluses as the major objective of the fiscal policy. However, these institutions had the primary fiscal revenue as the adjustment variable, without worrying about the accelerated growth in government spending. Thus, they proved to be unsustainable in the long run. Not even the rules established by the Law of Fiscal Responsibility, which were supposed to limit public expenditures, were effective to contain the government spending expansion, thus reflecting the fragility of the fiscal instance in Brazil. Therefore, as agued by Aoki (2001), a new policy rule that cannot shift agents' expectations to commit to compliance might have no effect and might be too weak. A rule that restricts or establishes a particular behavior is effective only if individuals expect other agents, including those responsible for enforcing the rule, to act in a way that makes it applicable and effective. 


\section{Discussion}

This paper investigated the relationship between the level of institutional quality and the cyclical properties of the fiscal and monetary policies in the Brazilian economy in the period from 1997 to 2017. More specifically, we investigated how the institutional quality behind the implementation of fiscal and monetary policies might influence their cyclical orientations. We extend the monetary and fiscal policy rules proposed by Taylor (2000) to incorporate a proxy variable for institutional quality. Following Calderón et al. (2016), we added an interaction term between output gap and the institutional quality indicator in the reaction functions of both macroeconomic policies. The Markov-Switching model was applied to account for the possibility of change in regime during the sample period.

The results indicated the existence of three distinct regimes for the monetary policy. This policy is significantly countercyclical in periods of higher of institutional quality, defined as strict control of the policy interest rate to achieve price stabilization. On the other hand, monetary policy was significantly pro-cyclical in periods of lower levels of institutional quality, where the policy instrument deviated from the primary policy objectives.

The Markov-Switching model identified two policy regimes for the fiscal policy. Under the first regime, the policy was significantly pro-cyclical. This regime predominated for over $78 \%$ of the sample period and was highly persistent, suggesting a strong tendency of pro-cyclical behavior in the conduction of the Brazilian fiscal policy. In periods of economic growth, with increasing in tax revenues, primary government expenditure expanded without prejudice of the primary surplus. However, in periods of recession or low economic growth, this strategy did not work and resulted in significant deterioration of the fiscal result.

The second regime was characterized by anticyclical behavior of the fiscal policy and presented very low frequency (22\% of the sample) when compared to the first regime (78\%). This regime was mostly prevalent in the years following the outbreak of the international financial crisis in 2008, persisting until 2011, when fiscal policy returned to its typical pro-cyclical guidance. The two major fiscal institutions, represented by primary surplus targeting regime and Law of Fiscal Responsibility, were not able to achieve their primary objectives of controlling the government expenditures and stabilizing the business cycle. Thus, the pro-cyclical guidance is directly associated with institutional weakness in the fiscal instance.

Our results suggest that both monetary and fiscal policy are significantly countercyclical in periods that exhibit higher levels of institutional quality, and they are pro-cyclical or acyclic in periods that exhibit lower levels of institutional quality. Thus, the quality level of institutions plays a key role in the government's ability to implement countercyclical monetary and fiscal policies to stabilize the business cycle in the Brazilian economy.

\section{Acknowledgments}

The authors would like to thank participants in the XLVIII meeting of the Brazilian Economic Association (ANPEC) for comments and suggestions. J. A. Divino acknowledge financial support from CNPq of Brazil. This study was financed in part by the Coordenação de Aperfeiçoamento de Pessoal de Nível Superior - Brasil (CAPES) - Finance Code 001. All remaining errors are the authors' sole responsibility.

\section{References}

Acemoglu, D., Johnson, S., \& Robinson, J. A. (2003). Institutional causes, macroeconomic symptoms: Volatility, crises and growth. Journal of Monetary Economics, 50(1), 49-123. http://dx.doi.org/10.1016/S0304-3932(02)00208-8

Acemoglu, D., Johnson, S., \& Robinson, J. A. (2005). Institutions as a fundamental cause of long-run growth. Handbook of Economic Growth, 1, 385-472. http://dx.doi.org/10.1016/S1574-0684(05)01006-3

Alesina, A., Campante, F. R., \& Tabellini, G. (2008). Why is fiscal policy often procyclical? Journal of the European Economic Association, 6(5), 1006-1036. http://dx.doi.org/10.2139/ssrn.780225

Aoki, M. (2001). Towards a Comparative Institutional Analysis. MIT press. https://doi.org/10.1007/978-981-13-2757-5_25

Braun, M. (2001). Why is fiscal policy procyclical in developing countries? Harvard University.

Calderón, C., Duncan, R., \& Schmidt - Hebbel, K. (2016). Do good institutions promote countercyclical macroeconomic policies? Oxford Bulletin of Economics and Statistics, 78(5), 650-670. https://doi.org/10.1111/obes.12132

Duncan, R. (2016). Institutional quality, the cyclicality of monetary policy and macroeconomic volatility. Journal of Macroeconomics, 39, 113-155. https://doi.org/10.1016/j.jmacro.2013.11.004 
Ellery, R., Gomes, V., \& Sachsida, A. (2002). Business cycle fluctuations in Brazil. Revista Brasileira de Economia, 56(2), 269-308. https://doi.org/10.1590/S0034-71402002000200004

Frankel, J., Vegh, C., \& Vuletin, G. (2011). On graduation from procyclicality. NBER Working Paper, 17619, p. 4. https://doi.org/10.1016/j.jdeveco.2012.07.001

Gadelha, A., \& Divino, J. A. (2019). Institutions, growth and economic stability. Economics Bulletin, 39(1), 554-563.

Galí, J., \& Perotti, R. (2003). Fiscal policy and monetary integration in Europe. Economic Policy, 18(37), 533-572. https://doi.org/10.1111/1468-0327.00115_1

Gavin, M., \& Perotti, R. (1997). Fiscal Policy in Latin America. NBER Macroeconomics Annual, 12, 11-61.

Gobetti, S. W. (2014). Regras fiscais no Brasil e na Europa: Um estudo comparativo e propositivo. Texto para Discussão, Instituto de Pesquisa Econômica Aplicada (IPEA).

Hamilton, J. D. (2010). Regime switching models. In Macroeconometrics and time series analysis (pp. 202-209). Palgrave Macmillan, London. https://doi.org/10.1057/9780230280830_23

Hodrick, R. J., Prescott, E. C. (1997). Postwar US business cycles: an empirical investigation. Journal of Money, Credit, and Banking, 1-16. https://doi.org/10.2307/2953682.

Holland, M. (2005). Monetary and exchange rate policy in Brazil after Inflation targeting. XXXIII Encontro Nacional de Economia da ANPEC, Natal, RN.

Ilzetzki, E. (2007). Rent-Seeking Distortions and Fiscal Procyclicality. University of Maryland. https://doi.org/10.1016/j.jdeveco.2010.07.006

Ilzetzki, E., \& Végh, C. A. (2008). Procyclical fiscal policy in developing countries: Truth or fiction? National Bureau of Economic Research.

Kaminsky, G., Reinhart, C., \& Végh, C. (2004). When it rains, it pours: Procyclical macropolicies and capital flows. NBER Macroeconomics Annual, 11-53.

King, R. G., \& Rebelo, S. (1993). Low Frequency Filtering and Real Business Cycles. Journal of Economic Dynamics and Control, 17, 207-231. https://doi.org/10.1016/S0165-1889(06)80010-2

Krolzig, H. M. (1997). Markov-switching vector autoregression. Lecture Notes in Economic and Mathematical Systems.

Lane, P. (2003). The Cyclical Behavior of Fiscal Policy: Evidence from the OECD. Journal of Public Economics, 87, 2661-2675. https://doi.org/10.1016/S0047-2727(02)00075-0

Mailhos, J., \& Sosa, S. (2000). El comportamiento cíclico de la política fiscal en Uruguay. Montevideo, Ceres.

Manasse, P. (2006). Procyclical fiscal policy: shocks, rules, and institutions: A view from MARS. International Monetary Fund. http://dx.doi.org/10.5089/9781451862874.001

Melitz, J. (2000). Some Cross-country Evidence about Fiscal Policy Behaviour and Consequences for EMU. Department of Economics, Fraser of Allander Institute.

North, D. C. (1991). Institutions. Journal of Economic Perspectives, 5(1), 97-112.

Sanchez De Cima, M. (2003). The Political Economy of Pro-Cyclical Fiscal Policy in Mexico, 1970-1988. Working Paper (CIS, University of Southern California).

Strawczynski, M., \& Zeira, J. (2007). Cyclicality of Fiscal Policy in Israel. Discussion Paper No. 2007.04 (Bank of Israel).

Sturzenegger, F., \& Werneck, R. (2006). Fiscal Federalism and Procyclical Spending: The Cases of Argentina and Brazil. Mimeo (Universidad Di Tella and PUC).

Talvi, E., \& Vegh, C. A. (2005). Tax Base Variability and Procyclical Fiscal Policy in Developing Countries. Journal of Development Economics, 78, 156-190. https://doi.org/10.1016/j.jdeveco.2004.07.002

Taylor, J. B. (2000). Reassessing Discretionary Fiscal Policy. The Journal of Economic Perspectives, 14, 21-36. https://doi.org/10.1257/jep.14.3.21

Vegh, C. A., \& Vuletin, G. (2012). Overcoming the fear of free falling: Monetary policy graduation in emerging markets. National Bureau of Economic Research. https://doi.org/10.1142/9789814449922_0006 


\section{Notes}

Note 1. The International Country Risk Guide includes a political risk index that corresponds to the sum of 12 partial measures of institutional quality: Government Stability (up to 12 points), Socioeconomic Conditions (12 points), Investment Profile (12 points), Internal Conflict (12 points), External Conflict (12 points), Corruption (6 points), Military in Politics (6 points), Religious Tensions (6 points), Law and Order (6 points), Ethnic Tensions (6 points), Accountability (6 points) and Quality of Bureaucracy (4 points).

Note 2. See Hamilton (2010) and Krolzig (1997) for details on the statistical properties of the model.

Note 3. See Ellery, Gomes and Sachsida (2002), for instance, for a comparison among alternative methods to estimate the output gap for Brazil.

Note 4. The consolidated public sector primary result (in percentage of GDP) and the tax revenue were also used as proxies for the fiscal result, but the central government primary expenditure was a better proxy in the Markov-Switching estimation, making the interpretation of the results clearer.

Note 5. All time series were transformed in logarithms, so that the cyclical components of the variables were expressed in terms of percentage deviations from a trend as computed from the HP filter.

Note 6. The modified Akaike information criterion was applied to select the optimal number of lags. According to the test results, the cyclical components of interest rate, inflation and exchange rate were stationary according to at least one of the no-break unit root tests. Exchange rate was stationary was stationary according to both tests and so was not included in the break test.

Note 7. See, for instance, Woodford (2003) for a detailed discussion on the Taylor principle.

\section{Appendix}

Table A1. Unit root tests: without and with structural breaks

\begin{tabular}{|c|c|c|c|c|c|c|c|c|c|c|}
\hline \multirow{3}{*}{ Variables } & \multicolumn{4}{|c|}{$\mathrm{MADF}^{\mathrm{GLS}}$} & \multicolumn{4}{|c|}{$\mathrm{MPP}^{\mathrm{GLS}}$} & \multirow{2}{*}{\multicolumn{2}{|c|}{$\begin{array}{c}\text { Perron (1997) } \\
\text { Model (C) }\end{array}$}} \\
\hline & \multicolumn{2}{|c|}{ Trend and constant } & \multicolumn{2}{|c|}{ Constant } & \multicolumn{2}{|c|}{ Trend and constant } & \multicolumn{2}{|c|}{ Constant } & & \\
\hline & t-Stat & Lag & t-Stat & Lag & MZ-t & Lag & MZ-t & Lag & t-Stat & Quebra Estrutura \\
\hline Primary expenditure & $-1,2280$ & 11 & $-1,3177$ & 11 & 0,6914 & 11 & 0,7598 & 11 & $-14,8443 * * *$ & 2010M09 \\
\hline Output gap & $-1,9266$ & 12 & $-0,7596$ & 12 & $-1,8018$ & 12 & $-1,0026$ & 12 & $-8,4859 * * *$ & 1997M11 \\
\hline Inflation & $-2,3204$ & 13 & $-1,3390$ & 13 & $-2,9864 * *$ & 13 & $-1,5311$ & 13 & $-5,1257^{*}$ & 2002M08 \\
\hline Interest rate & $-2,6537 *$ & 13 & $-1,9414^{*}$ & 13 & $-2,5515$ & 13 & $-1,7353^{*}$ & 13 & $-6,3483 * * *$ & 1998M03 \\
\hline Institutional quality & $-1,6704$ & 14 & $-0,6946$ & 6 & $-1,2396$ & 14 & $-0,7266$ & 6 & $-12,7924 * * *$ & 1998M04 \\
\hline Exchange rate & $-3,7739 * * *$ & 2 & $-3,4769 * * *$ & 2 & $-3,8467 * * *$ & 2 & $-3,5627 * * *$ & 2 & & 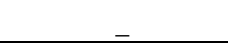 \\
\hline
\end{tabular}

Note. $* * *, * *$ and $*$ denote statistical significance at $1 \%, 5 \%$ and $10 \%$ levels, respectively. The optimal number of lags was chosen according to the Modified Akaike information criterion (MAIC), departing from a maximum of 15 lags. The time series used in the tests are expressed in terms of cyclical components, with the exception of the index representing the institutional quality. The critical values of the MADFGLS test are: (i) model with constant: $-2.57(1 \%) ;-1.94(5 \%)$; and $-1.61(10 \%)$; (ii) model with constant and trend: $-3.46(1 \%) ;-2.92(5 \%)$; -2.62 (10\%). The critical values of the MPPGLS test are: (i) model with constant: $-2.58(1 \%)$; -1.98 (5\%); and -1.62 (10\%); (ii) model with constant and trend: $-3.42(1 \%) ;-2.91(5 \%) ;-2.62(10 \%)$. For the Perron (1997) test, the critical values are: $-5.72(1 \%),-5.18(5 \%)$ and -4.89 $(10 \%)$. The date of the structural break is endogenously estimated from the data.

\section{Copyrights}

Copyright for this article is retained by the author(s), with first publication rights granted to the journal.

This is an open-access article distributed under the terms and conditions of the Creative Commons Attribution license (http://creativecommons.org/licenses/by/4.0/). 